\section{Basaloid Squamous Cell Carcinoma on the Skin of the Hand}

Tae Hoon Kim ${ }^{1}$, Jongho Lee ${ }^{1}$, Iehyon Park ${ }^{1}$, Ji Ung Park ${ }^{2}$, Sung Tack Kwon ${ }^{1}$

${ }^{1}$ Department of Plastic and Reconstructive Surgery, Seoul National University College of Medicine, Seoul; ${ }^{2}$ Department of Plastic and Reconstructive Surgery, Seoul National University Boramae Medical Center, Seoul, Korea

\begin{abstract}
Correspondence: Ji Ung Park
Department of Plastic and Reconstructive Surgery, Seoul National University Boramae Medical Center, Seoul National University College of Medicine, 20 Boramae-ro 5-gil, Dongjak-gu, Seoul 07061, Korea Tel: +82-2-870-2332, Fax: +82-2-831-2826, E-mail: alfbskan@gmail.com
\end{abstract}

This material was presented at the 71st International Congress of the Korean Society of Plastic and Reconstructive Surgeons on November 1-3, 2013 in Seoul, Korea.

No potential conflict of interest relevant to this article was reported.

Received: 1 Jun 2015 • Revised: 29 Jun 2015• Accepted: 27 Aug 2015 pISSN: 2234-6163 • elSSN: 2234-6171

http://dx.doi.org/10.5999/aps.2015.42.6.808 • Arch Plast Surg 2015;42:808-810 Copyright (C) 2015 The Korean Society of Plastic and Reconstructive Surgeons This is an Open Access article distributed under the terms of the Creative Commons Attribution Non-Commercial License (http://creativecommons.org/licenses/by-nc/3.0/) which permits unrestricted non-commercial use, distribution, and reproduction in any medium, provided the original work is properly cited.

Basaloid squamous cell carcinoma (BSCC), an uncommon tumor with a predilection for the upper aerodigestive tract, is considered a distinct variant of squamous carcinoma due to its unique histological features and aggressive clinical behavior $[1,2]$. To the best of our knowledge, BSCC with a primary origin

Fig. 1.

Photograph of primary basaloid squamous cell carcinoma on the skin of the dorsal side of the right third finger. in the skin is extremely rare, although metastatic deposits of this type of cancer have been reported on the skin $[3,4]$. In this report, we present an unusual case of primary BSCC of the skin of the hand.

An 89-year-old female presented with an exophytic mass on the dorsum of the proximal phalanx of the right third finger that had exhibited rapid growth. The mass was grossly measured to be approximately $1.5 \mathrm{~cm} \times 1.5 \mathrm{~cm}$, with irregularly protruding and ulcerative features (Fig. 1). A punch biopsy was performed by a dermatologist, and the pathology report found malignancy with skin surface necrosis and multifocal tumor cell necrosis. Chest computed tomography and positron emission tomography were performed as part of a metastatic work-up, but no evidence of metastasis was observed. A wide excision was made, with a $1.5-\mathrm{cm}$ peripheral margin, and the sheath of the extensor tendon was removed to ensure the complete removal of the tumor along the deep margin (Fig. 2). All frozen biopsies from the surgical margin were found to be negative, and a venous free flap with a $6-\mathrm{cm} \times 3.5-\mathrm{cm}$ skin paddle was harvested from the ipsilateral forearm. One proximal vein was anastomosed to the distal end of the digital artery,

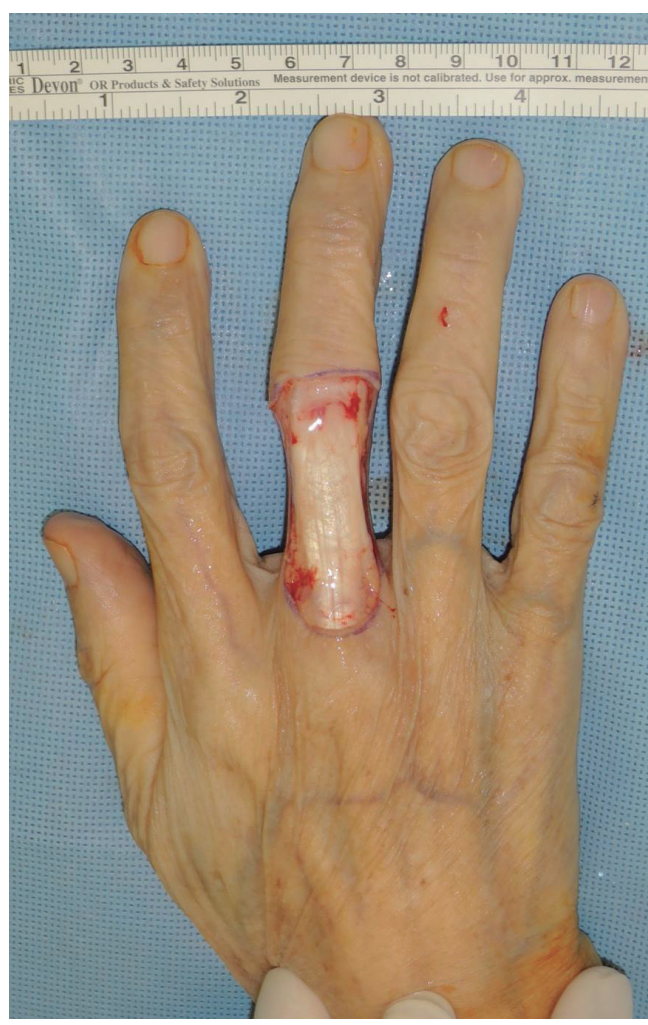

Fig. 2.

Intraoperative photograph after wide excision of the tumor. 
and the other three veins were anastomosed to the digital veins in a retrograde pattern (Fig. 3). No adjuvant chemotherapy or radiation was administered, and the patient was discharged seven days postoperatively. Pathological examination found that the tumor had a basaloid component, with lobules of small closely packed basaloid cells showing unique peripheral palisading and central comedonecrosis. The exaggerated nuclear-tocytoplasmic ratio of the tumor nests accounted for their basaloid appearance, which suggested a histological diagnosis of BSCC (Fig. 4). When a diagnosis of BSCC is suspected, it is important to evaluate the differential diagnosis with other diseases that have similar pathological or clinical features. A pathologist therefore performed an immunochemical evaluation. Immunohistochemistry, which played a substantive role in the diagnosis, showed a positive response for $\mathrm{Ki}-67$ and p63. Ki-67 is a nuclear protein found during the active phase of the cell cycle, while p63 enables BSCC to be distinguished from adenoid cystic carcinoma [5]. Moreover, other possible diagnoses were excluded through tests for MOC-31,

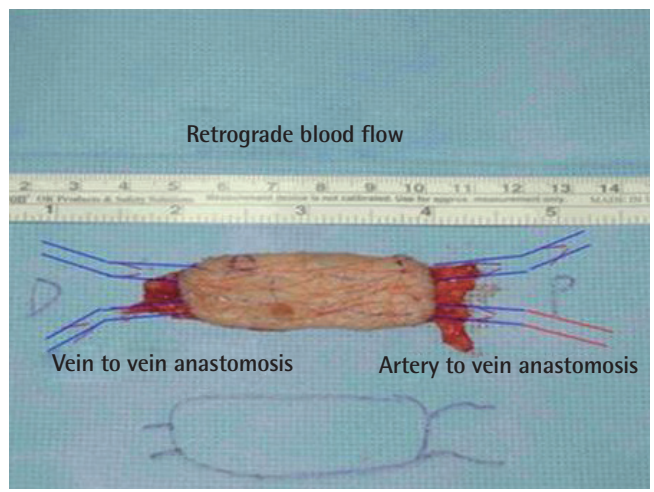

Fig. 3.

Schematic view of venous free flap harvest from the ipsilateral forearm.

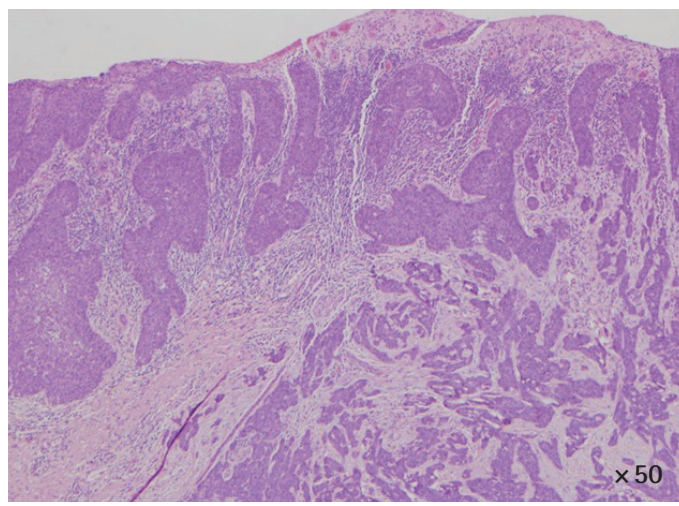

chromogranin, cytokeratin 20, and synaptophysin. MOC-31 is useful in diagnosing adenocarcinoma, and chromogranin is a protein found in endocrine tumors. Cytokeratin 20 and synaptophysin show that a cell is from gastric/intestinal mucosa cells or neuroendocrine cells, respectively.

The flap healed well, without any postoperative complications, and resulted in a natural contour of the dorsal finger (Fig. 5). During two years of subsequent follow-up, no local recurrence was observed. No signs of metastasis, such as the abnormal hypertrophy of a lymph node, were found.

BSCC is recognized to be an aggressive variant of squamous cell carcinoma. It is most frequently found in the head and neck area, especially the upper aerodigestive tract, in areas such as the supraglottic larynx, the base of the tongue, the palate, and the buccal cavity. However, BSCC has also been reported in the esophagus, thymus, anus, and cervix [1]. The differential diagnosis for BSCC includes adenoid cystic carcinoma and small cell carcinoma.

Distinguishing BSCC from adenoid cystic carcinoma can be difficult. Immunohistochemical staining is a

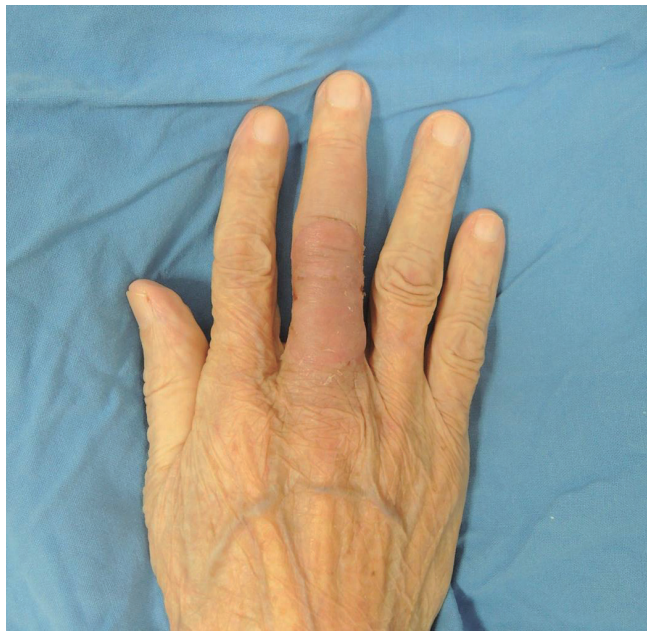

Fig. 5.

Postoperative photograph at a two-month follow-up visit.

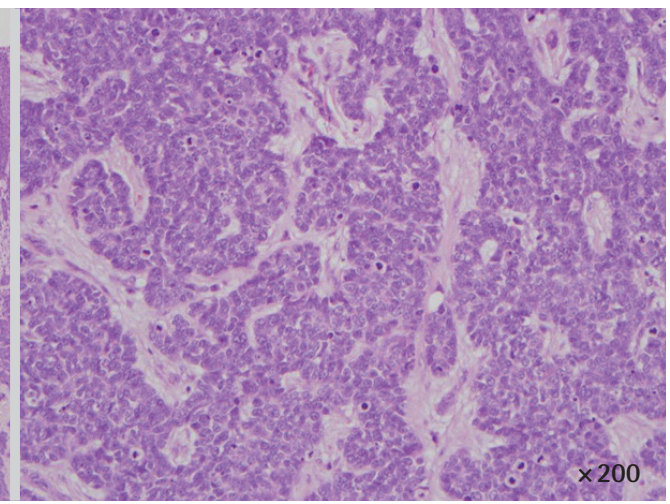

Fig. 4.

Hematoxylin and eosin-stained section, showing a mixture of superficial squamous cells and deep basaloid cells with a more aggressive tendency towards infiltration. 
useful method of distinguishing these two malignancies [5]. Early detection and treatment with a generous safety margin is paramount to reduce the risk of local recurrence and metastasis. After surgical treatment, careful follow-up is important.

We report a rare case of primary BSCC on the skin of the hand. BSCC is an uncommon, histologically distinct, high-grade variant of squamous cell carcinoma. This case adds to our knowledge of the clinical presentation and treatment of BSCC.

\section{References}

1. Paulino AF, Singh B, Shah JP, et al. Basaloid squamous cell carcinoma of the head and neck. Laryngoscope 2000;110:1479-82.

2. Cabanillas R, Rodrigo JP, Ferlito A, et al. Is there an epidemiological link between human papillomavirus DNA and basaloid squamous cell carcinoma of the pharynx? Oral Oncol 2007;43:327-32.

3. Ban JH, Lee JK, Jin SM, et al. Basaloid squamous cell carcinoma of the external auditory canal: case report. Eur Arch Otorhinolaryngol 2007;264:697-9.

4. Boyd AS, Stasko TS, Tang YW. Basaloid squamous cell carcinoma of the skin. J Am Acad Dermatol 2011;64:144-51.

5. Emanuel P, Wang B, Wu M, et al. p63 Immunohistochemistry in the distinction of adenoid cystic carcinoma from basaloid squamous cell carcinoma. Mod Pathol 2005; 18:645-50.
Simultaneous Reconstruction of Forefoot and Hindfoot Defects with a ThoracodorsalAxis Chimeric Flap

Jung Ho Lee ${ }^{1}$, Hae Won Kang ${ }^{1}$, Sue Min Kim², Young Joon Jun ${ }^{1}$, Young Jin Kim ${ }^{1}$

${ }^{1}$ Department of Plastic and Reconstructive Surgery, College of Medicine, The Catholic University of Korea, Bucheon; ${ }^{2}$ Department of Plastic and Reconstructive Surgery, Ajou University of Korea College of Medicine, Suwon, Korea

Correspondence: Jung Ho Lee

Department of Plastic and Reconstructive Surgery, College of Medicine, The Catholic University of Korea, 327 Sosa-ro, Wonmi-gu, Bucheon 14647, Korea Tel: +82-32-340-0759, Fax: +82-2-594-7230

E-mail: tfm0822@catholic.ac.kr

No potential conflict of interest relevant to this article was reported.

Received: 9 May 2015 • Revised: 8 Jun 2015 • Accepted: 19 Jun 2015 pISSN: 2234-6163 • elSSN: 2234-6171

http://dx.doi.org/10.5999/aps.2015.42.6.810 • Arch Plast Surg 2015;42:810-813

Copyright (C) 2015 The Korean Society of Plastic and Reconstructive Surgeons

This is an Open Access article distributed under the terms of the Creative Commons Attribution Non-Commercial License (http://creativecommons.org/licenses/by-nc/3.0/) which permits unrestricted non-commercial use, distribution, and reproduction in any medium, provided the original work is properly cited.

To achieve successful results in foot reconstruction, both form and function should be restored. The reconstruction of soft tissue should be durable against pressure and permit the patient to wear near-normal shoes. However, resurfacing plantar soft-tissue defects is often challenging for reconstructive surgeons because the soft tissue is not redundant, and the

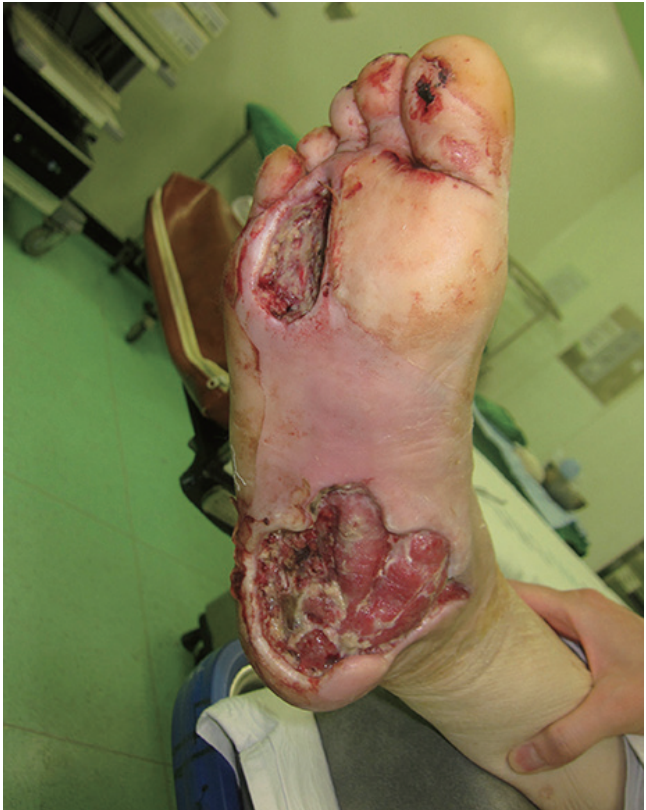

